The Sustainable City XII 559

\title{
TRANSSHIPMENT STATION FOR URBAN SOLID WASTE: AN ANALYSIS CONSIDERING CITY LOGISTICS CONCEPTS
}

\author{
LEISE KELLI DE OLIVEIRA ${ }^{1}$, RENATA LÚCIA MAGALHÃES DE OLIVEIRA ${ }^{2}$ \\ \& LILIAN SILVIA TEIXEIRA DE AVELAR RUEDA ${ }^{3}$ \\ ${ }^{1}$ Federal University of Minas Gerais, Brazil \\ ${ }^{2}$ Federal Center for Technological Education of Minas Gerais, Brazil \\ ${ }^{3}$ Municipality of Belo Horizonte, Brazil
}

\begin{abstract}
In this paper we analyze the impact of a transshipment station on the urban solid waste management, considering the trade-off among (i) transportation and operational costs of the transshipment; (ii) operational costs of the trips considering the transshipment station; and (iii) costs for the collection trips from the districts directly to the landfill. The study was carried out in the city of Belo Horizonte (Brazil), which produces 1,730 tons of urban solid waste per day. We have evaluated three scenarios: (i) baseline scenario, in which part of the solid waste is consolidated on a transshipment station and the other part is destined directly to the landfill; (ii) transport direct to the landfill; and (iii) consolidation of all solid waste on the transshipment station. We have evaluated these scenarios considering the cost of collecting and transporting the solid waste. We then analyzed the correlation between cost and distances: distance and total transportation cost have a positive correlation, and distance has a negative correlation with the unitary transportation cost $(\mathrm{R} \$ / \mathrm{km})$, i.e., when the distance increases, the cost of transportation per kilometer decreases. Our results indicate that the transshipment station has economic advantages for consolidating and transporting solid waste to a landfill. However, direct transport to a landfill is more profitable if the transportation cost $(\mathrm{R} \$ / \mathrm{km})$ increases up to $9.28 \%$. If the transportation cost increases more than $15 \%$, the operation cost of a transshipment station can increase up to $62 \%$. However, an efficient operation in the transshipment station is critical to ensure this level of profit. Finally, the location of the transshipment station is imperative, and baseline scenario presents a better network for the urban solid waste logistics management.
\end{abstract}

Keywords: urban waste management, transshipment station, urban freight transport.

\section{INTRODUCTION}

Urban freight transport is a fundamental activity for the maintenance of the urban lifestyle. However, urban waste is a cargo category not always welcome in urban areas [1], produced by domestic activities in urban dwellings (household waste) and as a result of sweeping, cleaning of public places and roads, and other urban cleaning services (municipal waste cleaning) [2]. Also, the collection and transportation of municipal solid waste (MSW) has economic and environmental impacts on the urban environment [3], besides being an important activity in the MSW management [4]. Still, economic competitiveness is fundamental in defining the location of facilities for MSW management [5].

The management of urban solid waste logistics is necessary with the increase of MSW and the need for the reuse of non-renewable resources [6]. In general, MSW logistics involves the collection of solid waste by compactor trucks with the capacity up to $15 \mathrm{~m}^{3}$; transportation to the transshipment stations consolidation of waste; and transportation using vehicles of higher capacity to the landfill. When there is no MSW consolidation at the transshipment stations, there is a direct transport to the landfill, as shown in Fig. 1.

According to [7], collection and transportation costs are high, and the service level is low (low collection frequency in the population viewpoint), and it is important to provide a regular service to improve the service level. 


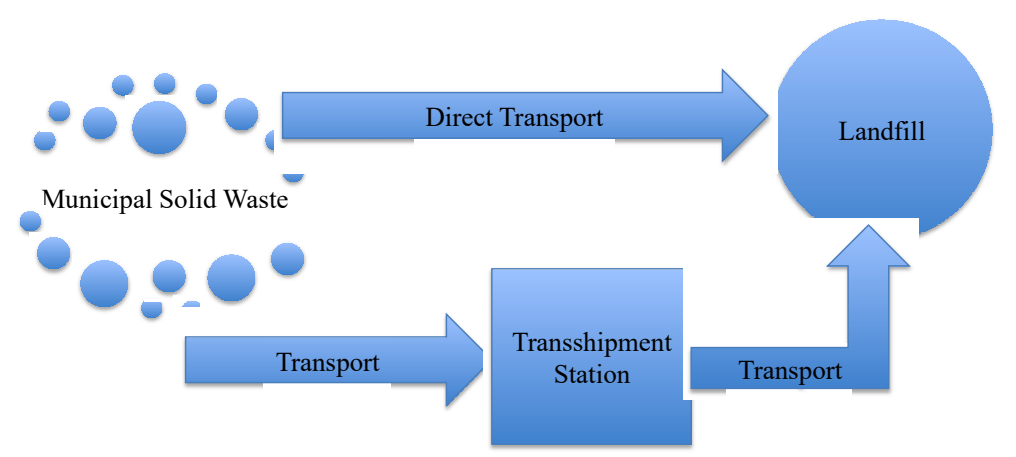

Figure 1: Typical logistics operation of municipal solid waste.

Considering the options for the shift of MSW to the landfill, the disposal of waste in areas closer to the place where it is generated eliminates the need for transshipment stations. Considering the transshipment process, it is important to analyze if the gathered costs considering (i) collection and transportation costs to the transshipment station, (ii) operational costs and (iii) the transportation cost to the landfill are less than the collection and transport costs directly to the landfill. According to [8], in general, the definition of the location of a transshipment station considers the minimization of transportation costs. For [7], the location choice of the transshipment station must meet: (i) exclusion criteria (swamps and flood plains, areas of protection of flora and fauna, areas of historical, cultural and archaeological protection, agricultural and coastal areas); (ii) community criteria (impact on air quality, local infrastructure, use of adjacent land, proximity to schools, churches, residential and leisure areas); and (iii) technical criteria (central and accessible location, adequate area and topography, and possibility of area expansion). Also, [7] indicates that the cost of collection and transportation can vary significantly depending on the location of the transshipment station.

In this context, the object of this study is the assessment of the transshipment station, one of the solid waste management stages regarding the Brazilian National Solid Waste Policy [2] and part of the MSW management system [8]. MSW transshipment stations are defined by [9] as a logistical facility that interconnects the solid waste collected to thelandfill, where the MSW is consolidated from multiple vehicles to vehicles of greater capacity, in order to obtain transportation savings for final disposal in a landfill. In [10], a similar concept is adopted.

According to [3], to reduce transport costs, the managers seek different strategies for collecting and transporting MSW. The transshipment stations allow reducing transportation costs through freight consolidation, with consequent reduction of fuel consumption, maintenance costs, urban traffic, and pollution [9], [10].

Thus, this paper assesses the benefits of a transshipment station to the MSW consolidation considering a case study in Belo Horizonte. For that, we have considered the trade-off between (i) the distance from the collection districts to the transshipment station; and (ii) the costs of collecting, transporting and operating the transshipment station. This evaluation is necessary since the literature shows different cases about urban waste logistics, detailed below.

In Abadan (Iran), the solid waste is transported directly to the landfill [11]. In Calcutta (India), a transshipment station to consolidate MSW in vehicles of greater capacity is used 
[11]. In Israel, there are 30 transshipment stations and the largest one is in the Tel Aviv Metropolitan Region, with an operational capacity of 3,000 tons of MSW per day [10]. In Urmia (Iran), the transshipment station is located $8 \mathrm{~km}$ south of the city, and the landfill is located $17 \mathrm{~km}$ to the north [12]. In São Paulo, there are five transshipment stations in different areas of the city with an estimated volume of 1,200 tons per day [13]. In [14], the existence of 3,500 transshipment stations in the USA in 1999 it is reported.

Among the studies that address the transshipment station, we highlight [9], who proposed a manual for guidance on the deployment and operation of transfer stations. [12], analyzed the effects of MSW management to reduce costs in Urmia (Iran). The results indicate that the use of a transshipment station, despite the proximity, is not economical due to the location (the station is located in the south of the city and the landfill in the north). [4], presented a survey that addresses urban waste logistics considering the reverse logistics approach. The authors identified a gap in the literature about reverse logistics on the urban environment and the importance of MSW management in logistics systems.

[10], analyzed the economic cost of externalities related to MSW transshipment stations in Israel. The main question is whether the proximity of MSW transshipment stations, considering environmental issues, impacts the sale price of the residences. The results indicated that transshipment stations generate discomfort for the population and suggest incorporating the impacts of the installation on the cost of land in locational studies of these logistical facilities.

[8], analyzed the location of a transshipment station from the environmental viewpoint to assess its feasibility as a logistics facility for the MSW management system. The authors identified a $16.8 \%$ reduction in the environmental impact when the transshipment station is an integral part of the MSW system. Also, the environmental impact is proportional to the distance and volume of MSW transported. If the transshipment station is implemented, the energy consumption contributes $45 \%$ to the environmental impact, which is compensated by the fuel economy. With these results, authors concluded that the use of the transshipment station is viable from the environmental point of view in eight cities of the Province of Castellón (Spain).

[10], estimated the economic value of externalities related to MSW transshipment stations in Israel. The authors found problems when the transshipment station is implemented within a radius of up to $2.8 \mathrm{~km}$ regarding residential areas. Also, the cost of the property increases by US\$ 5,000 for each additional kilometer from the residential area to the transshipment station. Thus, a $1 \%$ increase in the average distance of a residence from the transshipment station is associated with a $0.06 \%$ increase in the price of the property. The results point out the need for compensation policies to determine the location of transshipment stations.

[15], identified 13 studies that incorporate the location of the transshipment stations as a strategic issue of the MSW management, considering Operations Research as a methodological approach. The literature review shows focus on travel generation, travel time and cost reduction, mostly due to the large monetary sum involved in the management of urban solid waste.

[3], proposed a model to find the minimum route between the collection point and the landfill, considering collection, transference, and transport of the MSW. Using data from the metropolitan region of Calcutta (India), the authors obtained a reduction of $30 \%$ in the traveled distance in collection routes, which implies considerable transport savings.

This brief literature review shows the importance of the transshipment station for the MSW management and emphasizes that the distance and costs of collection, transportation, and operation of the transshipment station can have a direct impact on the total cost. Thus, 
the next section reports the MSW system in Belo Horizonte and draws comparisons with literature indicators.

\section{MUNICIPALITY SOLID WASTE MANAGEMENT IN BELO HORIZONTE (BRAZIL)}

Belo Horizonte, the capital of the Minas Gerais State, has a population of 2.5 million inhabitants that produced, in 2015, 631,279 tons of MSW, resulting in a rate of 252.51 kilos per year per capita or $0.67 \mathrm{~kg} /$ inhabitant/day.

In 2010, per capita expenditure regarding the MSW was R $\$ 114.73 /$ inhabitant in Belo Horizonte, considering the collection of $0.78 \mathrm{~kg} /$ inhabitant/day and collection and transport costs of $\mathrm{R} \$ 108.72 /$ ton (US $\$ 1 \approx \mathrm{R} \$ 3.09$, in February/2016). The total cost of collecting and transporting the MSW represented $5.89 \%$ of the city's expenses [16], (MSW is managed by the municipality in Belo Horizonte). Collection costs in low and middle-income countries represent, respectively, $80-90 \%$ and $50-80 \%$ of the total cost of MSW management for companies [3]. In Urmia (Iran), $60 \%$ of the expenses with MSW management are related to the collection and transportation, with an average cost of US\$ 114-120 [14].

In Fig. 2 we present indicators of the amount of MSW collected per capita and collection and transportation costs in the period from 2002 to 2015 in Belo Horizonte. It is possible to observe little variability in the per capita generation of MSW (average of 0.73 $\mathrm{kg} /$ inhabitant/day and standard deviation of $0.06 \mathrm{~kg} /$ inhabitant/day). In 2015, collection and transportation costs were $\mathrm{R} \$ 110.31 /$ ton, collecting $0.69 \mathrm{~kg} /$ inhabitants/day. From 2010 to 2015 , the collection and transportation costs increased $1.46 \%$.

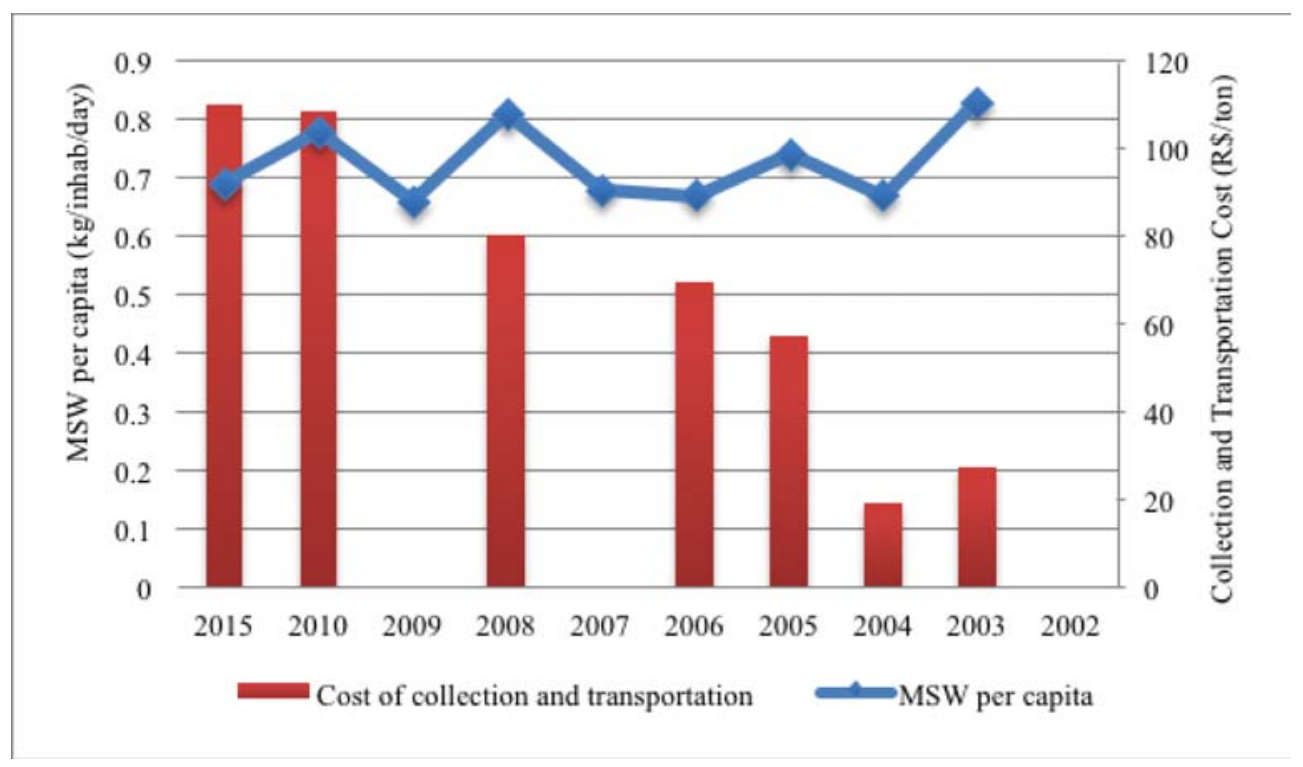

Figure 2: Indicators of MSW in Belo Horizonte. 


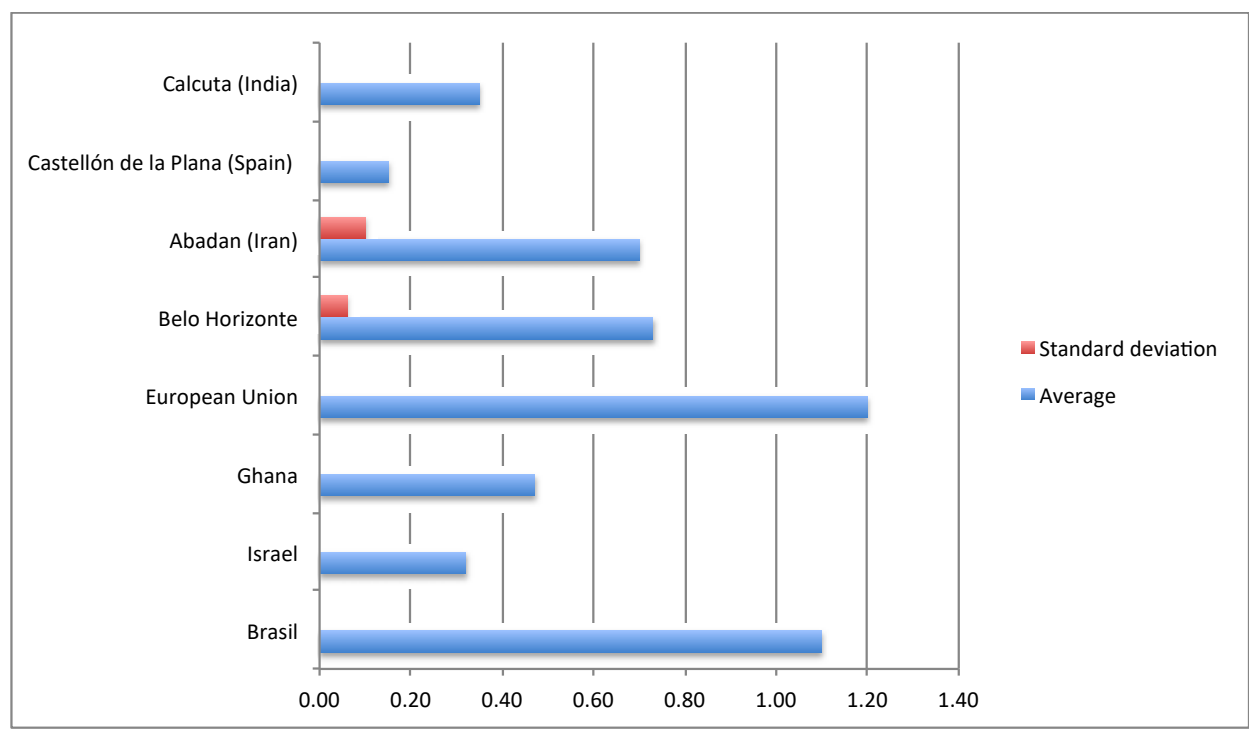

Figure 3: MSW per capita [3], [9], [11], [13], [16], [17].

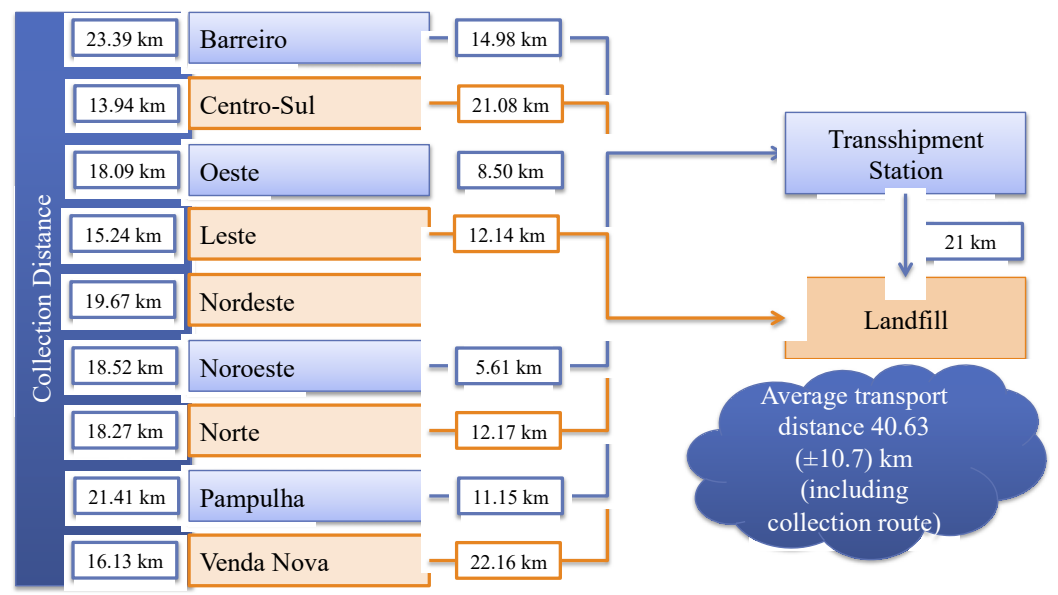

Figure 4: Logistics operation of the MSW in Belo Horizonte.

The per capita generation of MSW in Belo Horizonte is similar to Abadan (Iran), 209\% higher than Calcutta (India) and represents $63 \%$ of the residue per capita of Castellón de la Plana (Spain) (Fig. 3).

The logistics of MSW in Belo Horizonte is illustrated in Fig. 4. Belo Horizonte is divided into nine administrative regions, and the MSW of each administrative region has a specific destination: (i) for Barreiro, Oeste, Noroeste and Pampulha, the MSW is transported to the transshipment station; and (ii) for Centro-Sul, Oeste, Noroeste, Norte and Venda Nova, the MSW is transported directly to the landfill using compactor trucks. The average transport distance is $40.63 \mathrm{~km}$ ( \pm 10.7 of a standard deviation - SD), including the collection process. 
The transshipment station in Belo Horizonte is located at BR-040, km 531 and the warehouse occupies an area of $4,435 \mathrm{~m}^{2}$ to transfer the MSW from $15 \mathrm{~m}^{2}$ compactor trucks to $50 \mathrm{~m}^{3}$ trucks and then transport the waste to the landfill. The Macaúbas landfill is located at MG-5, km 8.1, in Sabará, a municipality near to Belo Horizonte.

In 2015, 631,279 tons of MSW were transferred to the landfill, an average of 52,606 ( \pm $2,977)$ tons per month. In Fig. 5 we show the monthly movement of MSW in 2015, for Belo Horizonte. Each regional produces, on a monthly basis, an average of 70,142 $( \pm 17,045)$ tons of MSW. The 'Centro-Sul' Regional is responsible for $18 \%$ of the total MSW generated in Belo Horizonte, which has a daily collection to meet the MSW demand. On average, the region produces $5.59( \pm 1.79)$ tons of waste per square kilometer and $0.73( \pm 0.14)$ kilograms of waste per inhabitant per day. These data are detailed in Table 1.

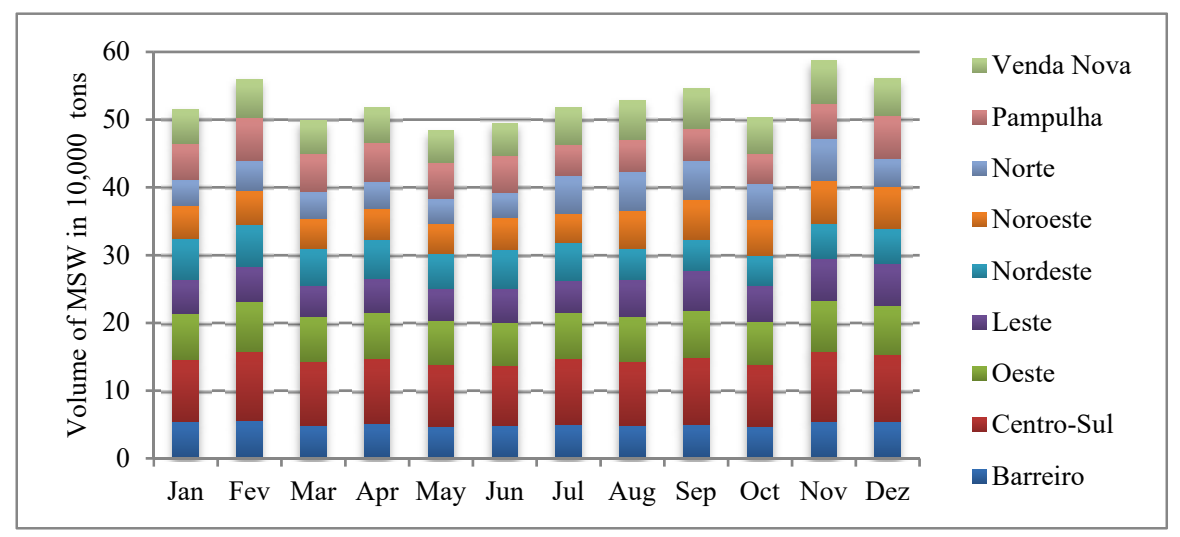

Figure 5: The amount of MSW in Belo Horizonte, in 2015.

Table 1: Details of MSW generation in Belo Horizonte.

\begin{tabular}{|l|c|c|c|c|}
\hline \multicolumn{1}{|c|}{ Regional } & $\begin{array}{c}\text { Percentage of } \\
\text { MSW generation }\end{array}$ & $\begin{array}{c}\text { Volume } \\
\text { (ton/day) }\end{array}$ & $\begin{array}{c}\text { Density } \\
\text { (ton/km²/day) }\end{array}$ & $\begin{array}{c}\text { Generation per capita } \\
\text { (kg/inhab./day) }\end{array}$ \\
\hline Barreiro & $10 \%$ & 6.99 & 3.14 & 0.59 \\
\hline Centro-Sul & $18 \%$ & 10.12 & 9.88 & 1.11 \\
\hline Oeste & $13 \%$ & 7.51 & 6.27 & 0.73 \\
\hline Leste & $10 \%$ & 7.21 & 6.20 & 0.73 \\
\hline Nordeste & $10 \%$ & 6.51 & 4.47 & 0.60 \\
\hline Noroeste & $10 \%$ & 6.50 & 5.62 & 0.63 \\
\hline Norte & $9 \%$ & 7.35 & 4.74 & 0.73 \\
\hline Pampulha & $10 \%$ & 6.01 & 3.41 & 0.77 \\
\hline Venda Nova & $10 \%$ & 5.89 & 6.06 & 0.67 \\
\hline Total & $100 \%$ & 64.09 & - & - \\
\hline Average & $11 \%$ & 7.12 & 5.54 & 0.73 \\
\hline SD & $\pm 3 \%$ & \pm 1.13 & \pm 1.79 & \pm 0.14 \\
\hline
\end{tabular}


The MSW produced by Barreiro, Oeste, Noroeste and Pampulha (43\%) is destined to the transshipment station and represents an annual volume of 268,764 tons. In this study, we analyze the impact of transporting this volume directly to the landfill.

\section{METHODOLOGICAL APPROACH}

In this study we have used the premises proposed by [9] to define the methodological approach, which is composed of the three steps:

- Step 1: (i) determine the cost of the transshipment station operation (R\$/ton) and (ii) determine the cost of collection and transportation to the transshipment station (R $\$ /$ ton);

- Step 2: (i) calculate the total cost $(\mathrm{R} \$ /$ ton. $\mathrm{km})$ and (ii) determine distances in different scenarios evaluated;

- Step 3: (i) analyze the scenarios.

The objective of the study is to assess the trade-off between the operation using the transshipment station and the trips directly to the landfill. For that, the break-even point (considering distance and cost) of the usage of the transshipment station was determined. Therefore, in step 1, the operation costs of the transshipment station, the costs of collection and transportation to the landfill, and to the transshipment station were obtained. In step 2, we calculated the total transport costs $(\mathrm{R} \$ /$ ton. $\mathrm{km})$ that supported the scenario analysis. In step 3, we analyzed the scenarios and determined the break-even point of the transshipment station operation, considering distance and total cost.

It is important to notice that the transshipment station is a suggested solution to reduce the impacts of collection and transportation of municipality solid waste in urban areas. The consolidation of the MSW in the transshipment station generates less vehicle traffic and, consequently, less noise and environmental pollution. A major challenge for public managers is to assess the distance from the collection districts to the transshipment station to get economically advantages in the consolidation process.

\section{RESULTS}

The following data were obtained from the Municipality of Belo Horizonte:

- distance from each collection district to the transshipment station and the landfill;

- volume of MSW from January to December of 2015, by region;

- cost of the collection, transportation and the operational cost of the transshipment station.

In Table 3 we present the costs' values considered in this study. The collection and transportation consider collecting MSW in each districts and transporting it to the final destination, according to Fig. 4 (landfill or transshipment station). The operational cost of the transshipment station (TS) includes (i) operational cost (41\%); and (ii) transport cost (59\%) from the transshipment station to the landfill. The total cost is the sum of collection and transportation costs, plus the operational cost of TS (if applicable). The unitary transportation cost considers the average distance traveled in Status Quo Scenario, presented in Fig. 4.

We have then analyzed three scenarios:

- $\quad$ status quo Scenario represented in Fig. 4;

- $\quad$ scenario one, in which all MSW is transported to the landfill; 
- scenario two, in which all MSW is transported to the transshipment station. This is a hypothetical scenario, but it is important to validate the status quo scenario.

In Table 3 we detail the distances in the scenarios analyzed. The results indicate the importance of the transshipment station to reduce the average distance traveled. In scenario two, we can notice the much higher distance $(+34 \%)$, indicating that operate all MSW in the transshipment station is not viable and has a negative impact on transportation costs (more distance traveled implies in an increase in the transportation cost). This result indicates that the status quo scenario is more viable than scenario two. Due to that, the following analysis presents a comparison the status quo scenario and the scenario one.

The results indicated that: (i) the total distance and the total cost have a positive correlation $(\rho=0.7)$, i.e., if the distance increases, total cost also increases; (ii) the total MSW volume and the total cost have no dependence $(\rho=-0.28)$; (iii) collection and transportation costs

Table 2: The costs' values considered in this study.

\begin{tabular}{|l|c|c|c|c|}
\hline Regional & $\begin{array}{c}\text { Cost of collection } \\
\text { and } \\
\text { transportation } \\
\text { (R\$/ton) }\end{array}$ & $\begin{array}{c}\text { Operational } \\
\text { cost of TS } \\
\text { (R\$/ton) }\end{array}$ & $\begin{array}{c}\text { Total Cost } \\
\text { (R\$/ton) }\end{array}$ & $\begin{array}{c}\text { Unitary } \\
\text { Transportation } \\
\text { Cost (R\$/ton.km) }\end{array}$ \\
\hline Barreiro & 98.18 & 22.00 & 120.18 & 3.17 \\
\hline Centro-Sul & 98.18 & 0.00 & 98.18 & 2.80 \\
\hline Oeste & 98.18 & 22.00 & 120.18 & 4.31 \\
\hline Leste & 93.81 & 0.00 & 93.81 & 3.39 \\
\hline Nordeste & 93.81 & 0.00 & 93.81 & 3.28 \\
\hline Noroeste & 93.81 & 22.00 & 115.81 & 4.50 \\
\hline Norte & 112.11 & 0.00 & 112.11 & 3.68 \\
\hline Pampulha & 112.11 & 22.00 & 134.11 & 4.06 \\
\hline Venda Nova & 112.11 & 0.00 & 112.11 & 2.93 \\
\hline
\end{tabular}

Table 3: Distances considered in different scenarios.

\begin{tabular}{|l|c|c|c|c|c|}
\hline Regional & $\begin{array}{c}\text { Status Quo } \\
\text { Scenario }\end{array}$ & $\begin{array}{c}\text { Scenario one } \\
\text { (landfill) }\end{array}$ & $\begin{array}{c}\text { Distance } \\
\text { Increase (\%) } \\
\text { status quo and } \\
\text { scenario one }\end{array}$ & $\begin{array}{c}\text { Scenario two } \\
\text { (transshipment } \\
\text { station) }\end{array}$ & $\begin{array}{c}\text { Distance } \\
\text { Increase (\%) } \\
\text { Status Quo and } \\
\text { Scenario two }\end{array}$ \\
\hline Barreiro & $59.37 \mathrm{~km}$ & $60.04 \mathrm{~km}$ & $1 \%$ & $59.37 \mathrm{~km}$ & $0 \%$ \\
\hline Centro-Sul & $35.02 \mathrm{~km}$ & $35.02 \mathrm{~km}$ & $0 \%$ & $51.06 \mathrm{~km}$ & $46 \%$ \\
\hline Oeste & $47.59 \mathrm{~km}$ & $46.33 \mathrm{~km}$ & $-3 \%$ & $47.59 \mathrm{~km}$ & $0 \%$ \\
\hline Leste & $27.68 \mathrm{~km}$ & $27.68 \mathrm{~km}$ & $0 \%$ & $54.43 \mathrm{~km}$ & $97 \%$ \\
\hline Nordeste & $28.62 \mathrm{~km}$ & $28.62 \mathrm{~km}$ & $0 \%$ & $61.15 \mathrm{~km}$ & $114 \%$ \\
\hline Noroeste & $45.13 \mathrm{~km}$ & $41.88 \mathrm{~km}$ & $-7 \%$ & $45.13 \mathrm{~km}$ & $0 \%$ \\
\hline Norte & $30.44 \mathrm{~km}$ & $30.44 \mathrm{~km}$ & $0 \%$ & $61.44 \mathrm{~km}$ & $102 \%$ \\
\hline Pampulha & $53.56 \mathrm{~km}$ & $41.68 \mathrm{~km}$ & $-22 \%$ & $53.56 \mathrm{~km}$ & $0 \%$ \\
\hline Venda Nova & $38.29 \mathrm{~km}$ & $38.29 \mathrm{~km}$ & $0 \%$ & $57.16 \mathrm{~km}$ & $49 \%$ \\
\hline Average & $40.63 \mathrm{~km}$ & $38.89 \mathrm{~km}$ & $-4 \%$ & $54.54 \mathrm{~km}$ & $34 \%$ \\
\hline SD & $10.75 \mathrm{~km}$ & $9.65 \mathrm{~km}$ & - & $5.49 \mathrm{~km}$ & - \\
\hline
\end{tabular}


We have used descriptive statistics to assess the data. Considering the Pearson correlation coefficient, the degree of correlation among the variables used in the study was evaluated. and distance do not have dependence; and (iv) the total distance has a negative correlation regarding the unitary transport cost $(\mathrm{R} \$ /$ ton. $\mathrm{km})(\rho=-0.94)$, i.e., if the distance increases, the unitary transport cost decreases. This statistical analysis indicates consistency in the data used.

In each scenario, we did three analyses:

- analysis one: economic impact on transporting all MSW from the collection districts to the landfill: what is the maximum distance between the collection districts and the landfill that results in an economically advantageous transport?

- analysis two: what is the operation cost of the transshipment station to make this station feasible?

- analysis three: sensitivity analysis of the total transportation cost: what is the maximum cost of collection and transportation ( $\mathrm{R} \$ /$ ton) that makes the transport to the landfill advantageous?

The results of all those analyses, considering the status quo scenario and the scenario one, are presented below.

\subsection{Analysis one}

In this analysis, we have considered the average distances traveled for each scenario and the respective unitary transportation cost to determine the economic impact of transporting all MSW directly to the landfill. The volume processed in the transshipment station represents $43 \%$ of the total volume collected in Belo Horizonte. The cost of collection and transportation represents $39 \%$ of the total cost. The operation of the transshipment station represents $8 \%$ of the total cost, from which $5 \%$ refers to the transport from the transshipment station to the landfill and 3\% are generated by the operational activities in the transshipment station.

\subsection{Analysis two}

In scenario two, we did a sensitivity analysis regarding the total transportation cost to identify values that made the collection and transportation to the landfill advantageous. In Table 5 we show the results of this analysis. Simulating an increase of up to $9.28 \%$ in the collection and transportation costs in the status quo scenario, the transport of all MSW to the landfill is more advantageous than operating the transshipment station at the cost of $\mathrm{R} \$ 22 /$ ton. With this increase, the costs of collecting, transporting and operating the transshipment station (status quo scenario) are same as the transportation costs to the landfill (scenario 1).

The results indicate that the growth of the operational costs of the transshipment station is closely related to the cost of collection and transportation. Also, the higher the increase in the collection and transportation costs, the greater the margin of growth regarding the transshipment station operational cost.

\section{CONCLUSION}

Transshipment stations are critical logistics facilities, which contribute to the logistical sustainability, through the reduction of the number of vehicles in the urban area (less congestion), lower emission of pollutants and improved operation of municipality solid waste management. However, it is necessary to observe the organizational structure, the operational 
Table 4: Sensitivity analysis of the transportation cost.

\begin{tabular}{|c|c|c|}
\hline $\begin{array}{c}\text { Growth in the cost } \\
\text { of Collection and } \\
\text { Transportation (\%) }\end{array}$ & $\begin{array}{c}\text { Increase of the Annual } \\
\text { Transportation Cost } \\
(\%)\end{array}$ & $\begin{array}{c}\text { Increase of the } \\
\text { operational cost } \\
\text { of the TS (\%) }\end{array}$ \\
\hline$<9.28 \%$ & $0 \%$ & $0 \%$ \\
\hline $10 \%$ & $1 \%$ & $8 \%$ \\
\hline $11 \%$ & $2 \%$ & $19 \%$ \\
\hline $13 \%$ & $3 \%$ & $40 \%$ \\
\hline $15 \%$ & $5 \%$ & $62 \%$ \\
\hline
\end{tabular}

efficiency considering scale and vehicles used, the financial viability, the environmental and traffic impacts regarding the transshipment station operation.

This study indicates that transshipment stations can be advantageous considering their location and may allow the consolidation of MSW and the reduction of the number of freight vehicles utilized to transport MSW to the landfill. However, the financial viability is related to the collection and transportation cost.

The scenario one (transport to the landfill) is feasible if the increase in the cost of collection and transportation does not exceed $9.28 \%$ and the operational cost of the transshipment station is up R $\$ 22$ per ton. Rises higher than $15 \%$ of the collection and transportation costs allow growths up to $62 \%$ in the operational cost of the transshipment station. Thus, for increases of more than $10 \%$ in the collection and transportation cost , a careful evaluation of the TS operational costs must be carried out to validate this cost (R $\$ 22$ per ton), making the operation of the transshipment station possible.

Finally, the transshipment station contributes to the improvement of the urban environment quality, since it reduces the pollutants emission. Thus, it is necessary to think about the city that we want and, consequently, to plan the municipality urban waste management. This planning should be aligned with this "desired" city, referring to operations that are not only financially viable, but also sustainable.

\section{ACKNOWLEDGEMENT}

The support of the National Council for Scientific and Technological Development (CNPq) is acknowledged and appreciated.

\section{REFERENCES}

[1] Al-Salem, S. M., Evangelisti, S. \& Lettieri, P., Life cycle assessment of alternative technologies for municipal solid waste and plastic solid waste management in the Greater London area. Chemical Engineering Journal, 244, pp. 391-402, 2014. doi: 10.1016/j.cej.2014.01.066.

[2] Brasil, Law No. 12,305, of August 2, 2010. Institutes the national policy on solid waste, 2010. Online, http://www.planalto.gov.br/ccivil_03/_ato2007-2010/2010/lei/ 112305.htm. Accessed on: 16 Mar. 2017 [in Portuguese].

[3] Das, S. \& Bhattacharyya, B.K., Optimization of municipal solid waste collection and transportation. Waste management, 43, pp. 9-18, 2015.

[4] Hickford, A. J. \& Cherrett, T.J., Developing innovative and more sustainable approaches to reverse logistics and the collection, recycling and disposal of waste 
products from urban centers. Transportation Research Group, University of Southampton, 2007.

[5] Khan, M.M., Jain, S., Vaezi, M. \& Kumar, A., Development of a decision model for the techno-economic assessment of municipal solid waste utilization pathways. Waste Management, 48, pp. 548-564, 2016.

[6] Bing, X., Bloemhof, J.M., Ramos, T. R. P., Barbosa-Povoa, A.P., Wong, C.Y. \& Vorst, J.G.A.J., Research challenges in municipal solid logistics management. Waste Management, 48, pp. 584-592, 2016. doi: 10.1016/j.wasman.2015.11.025.

[7] Sri Lanka, Solid waste collection, and transport; Service delivery training module $1 \mathrm{a}$ 4. Technical Report, 2008.

[8] Bovea, M.D., Ibáñez-Forés, V., Gallardo, A. \& Colomer-Mendonza, F.J., Environmental assessment of alternative municipal solid waste management strategies. A Spanish case study. Waste management, 30, pp. 2383-2395, 2010. doi: 10.1016/j.wasman.2010.03.001.

[9] EPA, Waste transfer stations: A manual for decision making. The United States Environmental Protection Agency. EPA530-R-02-002. Solid waste emergency response. Technical Report. Solid waste emergency response. Technical Report, 2002.

[10] Eshet, T., Baron, M. G., Shechter, M. \& Ayalon, O., Measuring externalities of waste transfer stations in Israel using hedonic pricing. Waste Management, 27, pp. 614-625, 2007.

[11] Babaei, A.A., Alavi, N., Goudarzi, G. \& Teymouri, P., Household recycling knowledge, attitudes and practices towards solid waste management. Resources, Conservation and Recycling, 102, pp. 94-100, 2015. doi: 10.1016/j.resconrec.2015.06.014.

[12] Jalizadeh, A. \& Parvaresh, A., Evaluation of chronological aspects of collection and transportation of municipal solid waste system in Urmia. Iranian Journal of Environmental Health Science and Engineering, 2(4), pp. 267-272, 2005.

[13] Jacob, P.R. \& Besen, G.R., Solid Waste Management in São Paulo: challenges of sustainability. Estudos avançados, 25, pp. 135-158, 2011 [in Portuguese].

[14] Wilson, B.G. \& Vicent, J.K. Estimating waste transfer station delays using GPS. Waste management, 28, pp. 1742-1750, 2008.

[15] Ghiani, G., Laganà, D., Manni, E., Musmanno, R. \& Vigo, D., Operations research in solid waste management: a survey of strategical and tactical issues. Computers \& Operations Research, 44, pp. 22-32, 2014.

[16] Brasil, National information system on solid waste management. Ministry of the Environment, 2016. Online, http://sinir.gov.br/web/guest/residuos-solidos-urbanos Accessed on 16 Mar. 2017 [in Portuguese].

[17] Miezah, K., Obiri-Danso, K., Kádár, Z., Fei-Baffoe, B. \& Mensah, M.Y., Municipal solid waste characterization and quantification as a measure towards effective waste management in Ghana. Waste Management, 46, pp. 15-27, 2015. 